\title{
Glutamate Transmission in the Nucleus Accumbens Mediates Relapse in Cocaine Addiction
}

\author{
Jennifer L. Cornish and Peter W. Kalivas \\ Department of Physiology and Neuroscience, Medical University of South Carolina, Charleston, South Carolina 29425
}

\begin{abstract}
Elevated dopamine transmission in the nucleus accumbens is thought to be a primary mediator of addiction to cocaine. However, repeated exposure to cocaine is associated with the recruitment of glutamate transmission. This poses the possibility that the behaviors characterizing cocaine addiction, such as craving-induced relapse, may not be preferentially mediated by dopamine transmission. An animal model of relapse was used to demonstrate that glutamate, and not dopamine transmission in the nucleus accumbens, is a primary mediator of cocaineinduced reinstatement of drug-seeking behavior. Reinstatement was produced by a systemic injection of cocaine or by the
\end{abstract}

microinjection of the glutamate receptor agonist AMPA or dopamine into the nucleus accumbens. It was found that microinjection of an AMPA receptor antagonist into the nucleus accumbens blocked reinstatement by all compounds, whereas a dopamine receptor antagonist was effective only in blocking reinstatement by intra-accumbens dopamine administration. These data suggest an important role for nucleus accumbens glutamate and not dopamine transmission in cocaine-induced relapse to drug-seeking behavior.

Key words: cocaine; relapse; glutamate; dopamine; nucleus accumbens; self-administration
Cocaine addiction is associated with a high incidence of relapse to drug taking that can manifest after years of abstinence from drug administration (Jaffe, 1990). Relapse to cocaine abuse arises from intense craving that can be triggered by a single drug-taking experience or from exposure to an environmental stimulus such as a stressor or a drug-associated cue (de Wit and Stewart, 1981; Worley et al., 1994; Erb et al., 1996; Childress et al., 1999). Acute cocaine administration produces an increase in dopamine transmission in the nucleus accumbens, a brain nucleus well recognized as a center of rewarding processes (Koob, 1988; Wise and Rompre, 1989), and manipulating dopamine transmission in the nucleus accumbens alters the rates of drug self-administration in animal models of cocaine addiction (McGregor and Roberts, 1993; Caine and Koob, 1994). In addition, the systemic administration of dopamine receptor agonists or antagonists have been shown to modulate drug-seeking behavior in animals experienced at cocaine or amphetamine self-administration (Ettenberg, 1990; Self et al., 1996; Weissenborn et al., 1996; de Vries et al., 1998). Thus, it is generally thought that relapse to drug taking involves dopamine transmission in the nucleus accumbens (Self and Nestler, 1998; Spealman et al., 1999), however the current lack of efficacy of dopaminergic pharmacotherapies on drug-addicted individuals highlights the need to investigate the role of additional neurotransmitters in the relapse process.

In addition to dopaminergic innervation from the ventral tegmental area (Swanson, 1982), the nucleus accumbens receives dense glutamatergic inputs from the prefrontal cortex, hippocampus, periventricular thalamus, and amygdala (Kelley et al., 1982; Phillipson and Griffiths, 1985; Groenewegen et al., 1987). Animal models of cocaine-induced neuroplasticity have demonstrated that increases in both dopamine and glutamate transmission in the nucleus accumbens are important for the development and

\footnotetext{
Received March 29, 2000; revised May 15, 2000; accepted May 24, 2000.

This research was supported by United States Public Health Service Grants DA12513 and MH40817 (P.W.K.). We thank the National Institute on Drug Abuse for the generous gift of cocaine $\mathrm{HCl}$ and Joycelyn $\mathrm{V}$. Kennedy for her technical assistance.

Correspondence should be addressed to Jennifer L. Cornish, Department of Physiology and Neuroscience, Medical University of South Carolina, 167 Ashley Avenue, Charleston, SC 29425. E-mail: cornishj@musc.edu.

Copyright (C) 2000 Society for Neuroscience $0270-6474 / 00 / 200001-05 \$ 15.00 / 0$
}

expression of the neuroadaptations postulated to underlie cocaine addiction (Pierce and Kalivas, 1997; Wolf, 1998). After withdrawal from repeated cocaine administration, a single cocaine injection leads to augmented dopamine and glutamate release and enhanced D1 receptor signaling in the nucleus accumbens (Pierce et al., 1996; Reid and Berger, 1996; White and Kalivas, 1998). In addition, inhibiting ionotropic AMPA receptors in the nucleus accumbens prevents the expression of the sensitized locomotor activity to cocaine (Pierce et al., 1996; Bell et al., 2000). These studies indicate an augmented role for both transmitters in the control of the nucleus accumbens after withdrawal from repeated cocaine administration. Recently, an operant animal model of relapse was used to show that stimulation of ionotropic glutamate receptors in the nucleus accumbens elicits cocaine-seeking behavior (Cornish et al., 1999). In the present study, reinstatement of lever pressing in cocaine-addicted rats was used to show that the stimulation of glutamate, but not dopamine receptors in the nucleus accumbens is critical for cocaine-induced reinstatement of drug-seeking behavior.

\section{MATERIALS AND METHODS}

All experiments were conducted according to specifications of the $\mathrm{Na}$ tional Institutes of Health Guide for the Care and Use of Laboratory Animals. Male Sprague Dawley rats were instrumented with jugular vein catheters and intranucleus accumbens cannulae and trained to lever press for intravenous infusions of cocaine in daily $2 \mathrm{hr}$ sessions. Methods detailing the self-administration apparatus and the implantation of intravenous catheters and intranucleus accumbens cannulae (anterior 1.2 $\mathrm{mm}$, lateral $1.5 \mathrm{~mm}$, and dorsal $6.5 \mathrm{~mm}$ from Bregma according to the

This article is published in The Journal of Neuroscience, Rapid Communications Section, which publishes brief, peer-reviewed papers online, not in print. Rapid Communications are posted online approximately one month earlier than they would appear if printed. They are listed in the Table of Contents of the next open issue of JNeurosci. Cite this article as: JNeurosci, 2000, 20:RC89 (1-5). The publication date is the date of posting online at www.jneurosci.org.

http://www.jneurosci.org/cgi/content/full/4403 
Figure 1. Effects of intra-accumbens treatment with the mixed dopamine receptor antagonist fluphenazine ( $F L U ; 10 \mathrm{nmol} /$ side), the AMPA receptor antagonist CNQX (1.0 $\mathrm{nmol} / \mathrm{side}$ ), and the NMDA receptor antagonist CPP $(0.1 \mathrm{nmol} /$ side $)$ on the drug-paired lever responses produced by a cocainepriming injection $(10 \mathrm{mg} / \mathrm{kg}$, i.p.). $A$ shows that the systemic administration of cocaine reinstated drug-seeking behavior that was not affected by dopamine receptor antagonism in the nucleus accumbens. $B$ illustrates that the intra-accumbens administration of CNQX completely blocked cocaine-induced drugseeking behavior. $C$ shows that pretreating the nucleus accumbens with CPP did not alter the ability for cocaine to induce drug seeking. $D$ shows the time course for the effect of intraaccumbens treatment with vehicle, FLU, CNQX, and CPP on the number of responses produced by the systemic prime of cocaine. $E$ shows the location of injection sites in the nucleus accumbens corresponding to each of the antagonists used in Figure 1. Average baseline responding before extinction for all animals used in Figure 1 was $44.2 \pm 4.2$ cocaine infusions. The number of determinations for each group is written in the solid bar of each treatment. The total number of animals used was 19. Data in $A-C$ are expressed as mean \pm SEM and were analyzed by a twoway repeated ANOVA (treatment group $\times$ treatment day). Each time point in $D$ represents the data expressed as mean number of active lever presses for successive 10 min intervals with the SEM bars eliminated for illustrative clarity, and the data were statistically evaluated using a two-way ANOVA with repeated measures over time. Post hoc comparisons were performed in each analysis using the least significant difference test of Milliken and Johnson (1984). NA, Nucleus accumbens. ${ }^{*} p<0.05$ for an increase in drug-paired lever responding compared to sham treatment day. $\# p<0.05$ for difference compared to vehicle-treated group. $+p<0.05$ for a difference with the vehicle treatment group.

atlas of Paxinos and Watson, 1986) are described by Cornish et al. (1999). Modifications of the previously reported protocols include the use of ketamine $\mathrm{HCl}(100 \mathrm{mg} / \mathrm{kg}$, Ketaset; Fort Dodge Animal Health, Fort Dodge, IA) and xylazine (12 mg/kg, Rompun; Bayer, Shawnee Mission, KS) to induce anesthesia, followed by Equithesin $(0.66 \mathrm{ml} / \mathrm{kg})$. From the day of surgery, intravenous catheters were flushed daily with cephalosporin $(15 \mathrm{mg} / 0.15 \mathrm{ml}$, Cefazolin Sodium; Apothecon, Princeton, $\mathrm{NJ}$ ) followed by streptokinase (200 IU/0.1 ml; Sigma, St. Louis, MO) in heparinized saline $(70 \mathrm{IU} / \mathrm{ml})$. One day before cocaine-self administration training, the rats were restricted to $20 \mathrm{gm} / \mathrm{d}$ of laboratory chow for the remainder of the study to aid in the acquisition of self-administration and to facilitate greater responding at the time of reinstatement (Comer et al., 1995). Acquisition of cocaine self-administration was also facilitated by using a higher dose of cocaine $(1 \mathrm{mg} / \mathrm{kg}$ per $0.5 \mu \mathrm{l}$ inf usion) for the initial 7-10 sessions (until $\pm 10 \%$ variation in responding over $3 \mathrm{~d}$ ) and then $0.5 \mathrm{mg} / \mathrm{kg}$ per infusion for $5 \mathrm{~d}$ to increase the number of lever presses to achieve greater reinstatement responding.

Rats were trained to self-administer cocaine by discriminating between an active (cocaine infusion) and inactive lever (no scheduled consequence) in the self-administration chamber. The rats were trained on a fixed ratio 1: time out $20 \mathrm{sec}$ schedule in daily $2 \mathrm{hr}$ sessions during the animals' light cycle. After $5 \mathrm{~d}$ of maintenance responding at the lower dose of cocaine, saline was substituted for cocaine to extinguish lever responding. Once the rats had reached criterion for extinguished selfadministration behavior (five or fewer saline inf usions plus five or fewer responses on the active lever during the $20 \mathrm{sec}$ time-out period), they were given a saline injection into the nucleus accumbens and/or peritoneum, depending on the treatment paradigm for the group. For animals that received only intra-accumbens treatment, saline was microinjected $(0.5 \mu \mathrm{l} / \mathrm{side})$ into the nucleus accumbens, and the subjects which underwent cocaine-induced reinstatement were given systemic saline $(1 \mathrm{ml} / \mathrm{kg}$, i.p.) 2 min after the microinjection of saline into the nucleus accumbens. Rats were placed into the self-administration chambers immediately after intra-accumbens or combined sham treatment, and the session began. The next day, rats were given intra-accumbens treatment alone or intra-accumbens treatment $2 \mathrm{~min}$ before systemic cocaine administration before the test session. Animals in the cocaine dose-response study were administered cocaine systemically immediately before the test session.

To assist in establishing appropriate doses of antagonist for the reinstatement experiments, the effect of antagonists on locomotor activity was evaluated in a separate group of animals. Rats were stereotaxically instrumented with bilateral cannulae in the nucleus accumbens (see above) and were pretreated with intra-accumbens saline, fluphenazine (10 or $30 \mathrm{nmol} /$ side), 6-cyano-7-nitroquinoxaline-2,3-dione (CNQX, 1.0 $\mathrm{nmol} / \mathrm{side})$, or ( \pm )-3-(2-carboxypiperazin-4-yl)-propyl-1-phosphonic acid
B AMPA Antagonist

C NMDA Antagonist
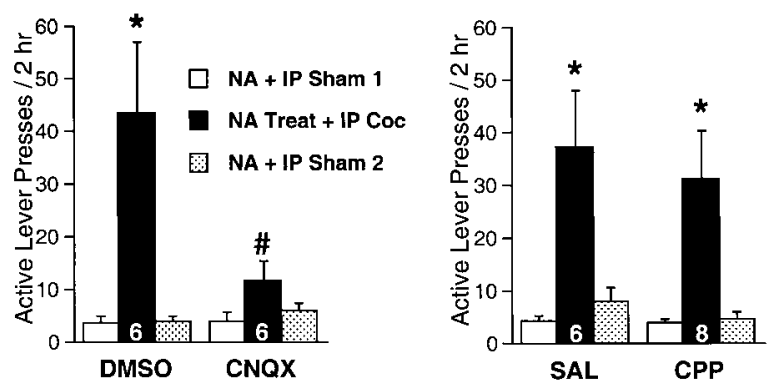

E
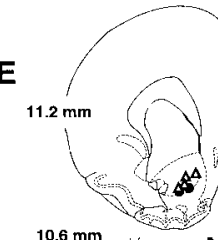

$10.6 \mathrm{~m}$

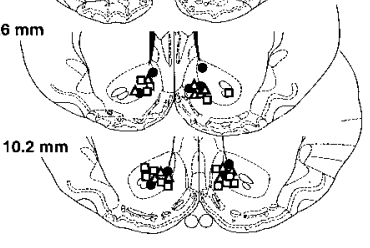

CPP, 0.1 or $1.0 \mathrm{nmol} / \mathrm{side}) 5 \mathrm{~min}$ before administering systemic cocaine or saline, or intra-accumbens coadministration of dopamine. Motor activity was quantified using photocell apparatus as described by Pierce et al. (1996)

At the completion of each study, cannula placement in the nucleus accumbens was verified in coronal tissue sections stained with cresyl violet (Cornish et al., 1999). All data shown were derived from animals with bilateral cannulae placement in the nucleus accumbens (Fig. 1E), and the majority of microinjections were in the medial $50 \%$ of the nucleus accumbens (Paxinos and Watson, 1986).

\section{RESULTS}

\section{Reinstatement of drug-seeking behavior by systemic cocaine administration is dose-dependent}

Rats that were trained to self-administer cocaine extinguished lever pressing to criterion levels 7-10 d after the introduction of saline infusions. Once cocaine-seeking behavior was extinguished, the rats were administered an injection of one of three doses of cocaine $(3,10$, or $30 \mathrm{mg} / \mathrm{kg}$, i.p.) to reinstate cocaineseeking behavior as measured by the number of responses on the lever previously paired with drug intake (active lever). The priming injection of cocaine produced a dose-dependent increase in responding on the drug-paired lever, which was not associated with increases in inactive lever presses (Table 1). Based on this dose-response analysis, the intermediate dose of cocaine $(10 \mathrm{mg} / \mathrm{kg}$, i.p.) was chosen to evaluate cocaine-induced reinstatement of lever pressing.

\section{Cocaine-induced drug-seeking behavior is dependent on AMPA and not dopamine receptor stimulation in the nucleus accumbens}

Systemic cocaine administration produced a significant increase in active lever presses that was not affected by microinjecting the broad spectrum dopamine receptor antagonist fluphenazine (Hyttel et al., 1985) into the nucleus accumbens (Fig. 1A). However, this dose of fluphenazine significantly antagonized cocaineinduced motor activity, and at the higher dose $(30 \mathrm{nmol})$ signif- 


\begin{tabular}{|c|c|c|c|}
\hline $\begin{array}{l}\text { Cocaine dose } \\
\text { (i.p.) }\end{array}$ & $3.0 \mathrm{mg} / \mathrm{kg}$ & $10 \mathrm{mg} / \mathrm{kg}$ & $30 \mathrm{mg} / \mathrm{kg}$ \\
\hline \multicolumn{4}{|l|}{ Active lever } \\
\hline Saline & $4.9 \pm 0.9(9)$ & $7.0 \pm 2.2(6)$ & $6.3 \pm 1.2(8)$ \\
\hline Cocaine & $11.0 \pm 2.4(9)$ & $53.8 \pm 11.1^{*}(6)$ & $30.7 \pm 1.9^{*}(8)$ \\
\hline \multicolumn{4}{|l|}{ Inactive lever } \\
\hline Saline & $1.7 \pm 0.6$ & $1.4 \pm 0.4$ & $1.8 \pm 0.5$ \\
\hline Cocaine & $2.4 \pm 1.2$ & $2.6 \pm 1.4$ & $1.7 \pm 0.6$ \\
\hline
\end{tabular}

Data are shown as mean \pm SEM lever presses performed in the $2 \mathrm{hr}$ session. The number of determinations for each treatment is shown in parentheses. Fourteen animals received up to three doses of cocaine or vehicle treatment. Baseline responding before extinction was $44.9 \pm 4.3$ cocaine inf usions.

${ }^{*} p<0.05$ for difference compared to saline-treated animals using a two-way ANOVA, followed by a least significant difference post hoc comparison.

icantly reduced the motor activity produced by a saline injection (Table 2). In contrast, intra-accumbens administration of the AMPA/kainate receptor antagonist CNQX completely inhibited cocaine-induced reinstatement of drug-seeking behavior (Fig. $1 B$ ) without affecting cocaine-induced locomotion (Table 2). Figure $1 D$ reveals that the decrease in lever pressing resulted from a significant reduction in responding during the first 20 min after cocaine injection. In contrast to AMPA/kainate receptor blockade, microinjection of the NMDA glutamate receptor antagonist CPP into the nucleus accumbens did not affect cocaine-induced drug-seeking behavior (Fig. $1 C$ ). This dose of CPP was also without significant effect on cocaine-induced motor activity, although a higher dose significantly increased basal locomotor activity (Table 2). None of the treatments produced an effect on inactive lever responses (data not shown). Figure $1 E$ displays the distribution of microinjection sites for each antagonist. Although all injection sites were in the nucleus accumbens, it remains possible that dorsal diffusion of antagonist into the striatum may have contributed to the effects of the microinjected drugs.

\section{AMPA-induced reinstatement is dopamine-independent}

To further evaluate the relative importance of dopamine and glutamate receptors in the accumbens in the relapse to cocaineseeking behavior, the reinstatement of lever pressing was initiated by directly stimulating either AMPA or dopamine receptors in the nucleus accumbens. Figure 2 shows that the microinjection of AMPA or dopamine into the nucleus accumbens elicited significant reinstatement of lever pressing. The blockade of AMPA/ kainate receptors by the co-inf usion of CNQX into the nucleus accumbens abolished reinstatement to either AMPA or dopamine administration, whereas fluphenazine inhibited only dopamine-induced lever responding. Reinstatement elicited by the intra-accumbens administration of dopamine was not affected by blocking NMDA receptors in the nucleus accumbens with CPP administration. None of the intra-accumbens treatments significantly altered inactive lever responses (data not shown) nor did antagonist administration alone affect lever pressing (Fig. 2C).

\section{DISCUSSION}

The present study demonstrates that cocaine-induced reinstatement of drug-seeking behavior depends on the stimulation of AMPA/kainate receptors in the nucleus accumbens. Moreover, whereas the stimulation of dopamine receptors in the nucleus accumbens can reinstate drug-seeking behavior, this is not the mechanism mediating reinstatement by systemic cocaine administration. Taken together, these data point to a prepotent role of glutamate transmission relative to dopamine transmission in the nucleus accumbens in the induction of relapse to cocaine-seeking behavior.

It is well established that the repeated injection of cocaine elicits a number of cellular and behavioral neuroadaptations that are manifested by a subsequent cocaine injection, including augmented motor stimulation (behavioral sensitization) and elevated dopamine transmission in the nucleus accumbens (White and Kalivas, 1998). Similar observations have been made in rats trained to self-administer cocaine (Hooks et al., 1994; Phillips and Di Ciano, 1996). The fact that these neuroadaptations persist for weeks after discontinuing repeated cocaine administration has focused much of the research into the neurobiology of craving on dopamine transmission in the nucleus accumbens (Self and Nestler, 1998; Spealman et al., 1999). This focus has been further justified by observations that systemically administered dopamine receptor agonists modulate the relapse of cocaine-seeking behavior in animal models akin to that used in the present study (Self et al., 1996; de Vries et al., 1999). Given these data it was surprising that cocaine-induced reinstatement was not inhibited

\begin{tabular}{|c|c|c|c|}
\hline Antagonist & $n$ & Vehicle & Motor stimulant \\
\hline Saline & 7 & $\begin{array}{l}\text { Saline i.p. } \\
4176 \pm 721\end{array}$ & $\begin{array}{l}\text { Cocaine, } 15 \mathrm{mg} / \mathrm{kg} \text {, i.p. } \\
30213 \pm 5828^{*}\end{array}$ \\
\hline Fluphenazine (10 nmol) & 7 & $3786 \pm 724$ & $11949 \pm 3006^{*}, * *$ \\
\hline Fluphenazine $(30 \mathrm{nmol})$ & 7 & $2125 \pm 322+$ & $11218 \pm 2204^{*}, * *$ \\
\hline DMSO $(1 \%)$ & 19 & $8859 \pm 852$ & $32501 \pm 3222 *$ \\
\hline CNQX $(1.0 \mathrm{nmol})$ & 19 & $9843 \pm 1529$ & $31147 \pm 2983^{*}$ \\
\hline Saline & 17 & $8430 \pm 1239$ & $26453 \pm 5313^{*}$ \\
\hline CPP $(0.1 \mathrm{nmol})$ & 7 & $7432 \pm 989$ & $21940 \pm 6315^{*}$ \\
\hline CPP $(1.0 \mathrm{nmol})$ & 10 & $\begin{array}{l}22012 \pm 3924+ \\
\text { Saline, intra-NA }\end{array}$ & $\begin{array}{l}32662 \pm 6274 \\
\text { Dopamine }(30 \mu \mathrm{g})\end{array}$ \\
\hline Saline & 5 & ND & $34833 \pm 4593$ \\
\hline Fluphenazine (10 nmol) & 5 & ND & $9179 \pm 2132^{* *}$ \\
\hline
\end{tabular}

Data are shown as mean \pm SEM photocell counts over 120 min after administration of cocaine or dopamine. The pharmacological antagonists (indicated as dose per side) were all microinjected into the nucleus accumbens 5 min before cocaine administration. When motor activity was elicited by dopamine in the nucleus accumbens, fluphenazine was microinjected into the nucleus accumbens simultaneously with dopamine. ND, Not done. NA, Nucleus accumbens.

${ }^{*} p<0.05$ comparing cocaine to saline using a two-way ANOVA and a paired Student's $t$ test with a Bonferonni adjustment for multiple comparisons.

$* * p<0.05$ comparing antagonist to saline or DMSO administration. 
A Dopamine $(30 \mu \mathrm{g} / \mathrm{side})$

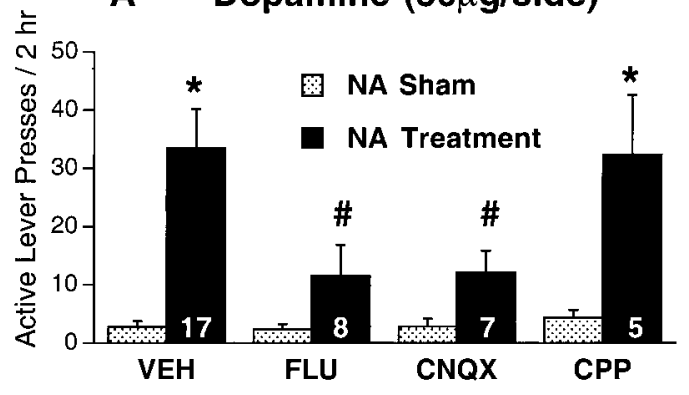

B AMPA (0.4 nmol/side)
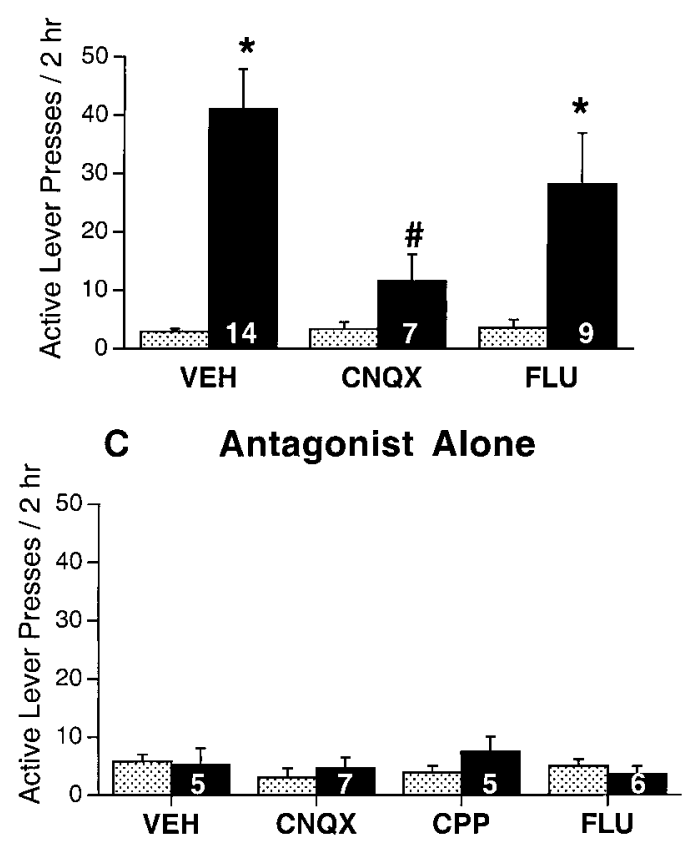

Figure 2. The effect of co-infusion of glutamate or dopamine receptor antagonists on intra-accumbens dopamine- or AMPA-induced drugpaired lever responses. $A$ displays the effect of fluphenazine (FLU; 10 nmol/side $),$ CNQX ( $1 \mathrm{nmol} / \mathrm{side})$, or CPP ( $0.1 \mathrm{nmol} / \mathrm{side})$ on the increase in responding on the drug-paired lever produced by the intra-accumbens administration of dopamine $(30 \mu \mathrm{g} / \mathrm{side}) . B$ shows effect of antagonists on the reinstatement of active lever pressing elicited by the microinjection of AMPA $(0.4 \mathrm{nmol} / \mathrm{side})$ into the nucleus accumbens. $C$ shows that there was no effect on reinstatement by microinjection of the antagonists alone. In all panels, $V E H$ represents pooled data from intra-accumbens salineand $1 \%$ DMSO (CNQX vehicle)-treated rats. Baseline responding before extinction for each panel was $45.0 \pm 3.5(n=23)(A), 38.4 \pm 4.3(n=17)$ $(B)$, and $40.0 \pm 3.0(n=20)(C)$ cocaine infusions. The number of determinations for each treatment is depicted in the solid bar. Data are expressed as mean \pm SEM and were analyzed using a two-way repeated measures ANOVA with post hoc comparisons made using the least significant difference test (Milliken and Johnson, 1984). ${ }^{*} p<0.05$ for increase in lever responses compared with sham treatment. \#p $<0.05$ for difference compared to VEH. NA, Nucleus accumbens.

by the administration of fluphenazine into the nucleus accumbens at a dose that clearly disrupts the motor-stimulant actions of cocaine, as well as inhibiting the capacity of intra-accumbens dopamine to induce reinstatement. The implications of this observation are twofold. (1) Dopamine projections outside of the nucleus accumbens are necessary for cocaine-induced reinstatement. This is consistent with an emerging literature that dopaminergic afferents to the amygdala modulate the reinstatement of cocaine-seeking behavior (Tran-Nguyen et al., 1998; Everitt et al., 1999) and that the systemic administration of a dopamine receptor antagonist has been shown to inhibit cocaine-seeking behavior
(Weissenborn et al., 1996). This effect is similarly observed with food-seeking behavior in which systemic (Chausmer and Ettenberg, 1997), but not intra-accumbens (Chausmer and Ettenberg, 1999), administration of a dopamine antagonist will disrupt this behavior. However, the capacity of dopamine microinjected into the nucleus accumbens to elicit drug-seeking behavior argues that activation of the mesoaccumbens projection is a sufficient stimulus to reinstate cocaine-seeking behavior. This is supported by the fact that modulating D1 receptor signaling by the intraaccumbens administration of compounds affecting protein kinase A (PKA) activity can initiate relapse to cocaine-seeking behavior (Self et al., 1998), although, altering PKA activity can also modulate AMPA receptor function (Banke et al., 2000). (2) The circuitry mediating cocaine-induced reinstatement of drugseeking behavior is distinct from cocaine-induced locomotor activation or the maintenance of cocaine self-administration. Both of the latter two cocaine-elicited behaviors are markedly disrupted by dopamine antagonist administration into the nucleus accumbens (Maldonado et al., 1993; Caine et al., 1995; Baker et al., 1998; Cornish et al., 1999), whereas the reinstatement of drug-seeking behavior is not.

Although dopamine transmission in the nucleus accumbens is not a necessary cellular event in cocaine-induced reinstatement, glutamate transmission at AMPA/kainate receptors is critical. Not only did AMPA/kainate receptor blockade in the accumbens block cocaine-induced reinstatement, but reinstatement of lever pressing by dopamine in the nucleus accumbens was antagonized by CNQX. Although surprising, this observation is consistent with recent imaging studies in human cocaine addicts showing that either cocaine- or cue-induced craving is associated with increased metabolic activity in the anterior cingulate cortex and amygdala (Grant et al., 1996; Childress et al., 1999), both of which provide dense glutamatergic innervation to the nucleus accumbens (Kelley et al., 1982; Christie et al., 1987). Moreover, after the repeated administration of cocaine in rats, re-exposure to the drug produces an enduring augmentation in extracellular glutamate in the nucleus accumbens (Pierce et al., 1996; Reid and Berger, 1996) that is partly blunted by electrolytic lesions of the dorsal prelimbic and anterior cingulate cortex (Pierce et al., 1998). In addition, whereas the acute motor response to cocaine was unaffected by AMPA/kainate receptor blockade in the nucleus accumbens (Table 2), the sensitized motor response to cocaine in animals pretreated with daily cocaine is inhibited by CNQX administration into the nucleus accumbens (Pierce et al., 1996; Bell et al., 2000). Finally, it was recently shown that electrical stimulation of the amygdala elicited the reinstatement of lever pressing in rats trained to self-administer cocaine (Hayes et al., 1999). Taken together with the present findings, these data support the hypothesis that the repeated exposure to cocaine produces enduring neuroadaptations that include the recruitment of glutamatergic afferents to the nucleus accumbens. Moreover, after repeated cocaine administration, the activation of these glutamatergic afferents emerges as a necessary neural event mediating cocaine-induced reinstatement of drug-seeking behavior and may reflect an addiction-associated decrease in the known interdependence of dopamine and glutamate transmission in regulating nucleus accumbens neurons (O'Donnell et al., 1999).

In contrast with the AMPA/kainate receptor subtype, the blockade of NMDA glutamate receptors did not alter cocaineinduced reinstatement. Although these data suggest that NMDA receptors in the nucleus accumbens are not involved in cocaineinduced relapse to drug seeking, the intra-accumbens administration of the NMDA receptor agonist 1-aminocyclobutane-cis-1,3dicarboxylic acid produces an increase in drug-seeking behavior (Cornish et al., 1999). Thus, stimulation of NMDA receptors may induce drug-seeking behavior, yet this is not a necessary mediator of the event. Interestingly, rats self-administer NMDA receptor antagonists directly into the nucleus accumbens (Carlezon and 
Wise, 1996) and have displayed drug-seeking behavior after systemic antagonist administration (de Vries et al., 1998). However, in the present study, the intra-accumbens administration of CPP alone did not alter lever responding, demonstrating that in cocaine-addicted animals NMDA receptor antagonism in the nucleus accumbens is not a significant stimulus to induce drugseeking behavior.

The present data demonstrate that the activation of AMPA/ kainate receptors in the nucleus accumbens is essential for the expression of drug craving induced by cocaine, whereas stimulation of dopamine receptors is not necessary. This observation parallels recent studies in cocaine addicts showing cravinginduced metabolic activation of glutamatergic cortical and allocortical brain regions that project to the nucleus accumbens. Taken together these data portray a prepotent role of glutamate transmission in the relapse to cocaine addiction and argue that AMPA/kainate glutamate receptor antagonists constitute an important new direction in the search for pharmacotherapies to treat craving-induced relapse in cocaine addiction.

\section{REFERENCES}

Baker DA, Fuchs RA, Specio SE, Khroyan TV, Neiswander JL (1998) Effects of intra-accumbens administration of SCH 23390 on cocaineinduced locomotion and conditioned place preference. Synapse 30:181-193.

Banke TG, Bowie D, Lee H-K, Huganir RL, Schousboe A, Traynelis SF (2000) Control of GluR1 AMPA receptor function by cAMPdependent protein kinase. J Neurosci 20:89-102.

Bell KB, Duffy P, Kalivas PW (2000) Context-specific enhancement of glutamate transmission by cocaine. Neuropsychopharmacology, in press.

Caine SB, Koob GF (1994) Effects of dopamine D1 and D2 antagonists on cocaine self-administration under different schedules of reinforcement in the rat. J Pharmacol Exp Ther 270:209-218.

Caine SB, Heinrichs SC, Coffin VL, Koob GF (1995) Effects of the dopamine D1 antagonist SCH 23390 microinjected into the accumbens, amygdala or striatum on cocaine self-administration in the rat. Brain Res 692:47-56.

Carlezon Jr WA, Wise RA (1996) Rewarding actions of phencyclidine and related drugs in the nucleus accumbens shell and frontal cortex. J Neurosci 16:3112-3122.

Chausmer AL, Ettenberg A (1997) A role for D2, but not D1, dopamine receptors in the response-reinstating effects of food reinforcement. Pharmacol Biochem Behav 57:681-685.

Chausmer A, Ettenberg A (1999) Intraaccumbens raclopride attenuates amphetamine-induced locomotion, but fails to prevent the responsereinstating properties of food reinforcement. Pharmacol Biochem Behav 62:299-305.

Childress AR, Mozely PD, McElgin W, Fitzgerald J, Reivich M, O’Brien CP (1999) Limbic activation during cue-induced craving. Am J Psychiatry $156: 11-18$.

Christie MJ, Summers RJ, Stephenson JA, Cook CJ, Beart PM (1987) Excitatory amino acid projections to the nucleus accumbens septi in the rat: a retrograde transport study utilizing $\mathrm{D}[3 \mathrm{H}]$ aspartate and [3H]GABA. Neuroscience 22:425-439.

Comer SD, Lac ST, Wyvell CL, Curtis LK, Carroll ME (1995) Food deprivation affects extinction and reinstatement of responding in rats. Psychopharmacology 121:150-157.

Cornish JL, Duffy P, Kalivas PW (1999) A role for glutamate transmission in the relapse to cocaine-seeking behavior. Neuroscience 93:1359-1367.

de Vries TJ, Schoffelmeer ANM, Binnekade R, Mulder AH, Vanderschuren LJMJ (1998) MK-801 reinstates drug-seeking behavior in cocaine-trained rats. NeuroReport 9:637-640.

de Vries TJ, Schoffelmeer AN, Binnekade R, Vanderschuren IJ (1999) Dopaminergic mechanisms mediating the incentive to seek cocaine and heroin following long term withdrawal of IV drug self-administration. Psychopharmacology 143:254-260.

de Wit H, Stewart J (1981) Reinstatement of cocaine-reinforced responding in the rat. Psychopharmacology 75:134-143.

Erb S, Shaham Y, Stewart J (1996) Stress reinstates cocaine-seeking behavior after prolonged extinction and a drug-free period. Psychopharmacology 128:408-412.

Ettenberg A (1990) Haloperidol prevents the reinstatement of amphetamine-rewarded runway responding in rats. Pharmacol Biochem Behav 36:635-638.

Everitt BJ, Parkinson JA, Olmstead MC, Arroyo M, Robledo P, Robbins TW (1999) Associative processes in addiction and reward. The role of amygdala-ventral striatal subsystems. Ann NY Acad Sci 877:412-438.

Grant S, London ED, Newlin DB, Villemagne VL, Liu X, Contoreggi C,
Phillips RL, Kimes AS, Margolin A (1996) Activation of memory circuits during cue-elicited cocaine craving. Proc Natl Acad Sci USA 93:12040-12045.

Groenewegen HJ, Vermeulen-Van der Zee A, Te Kortschot A, Witter MP (1987) Organization of the projections from the subiculum to the ventral striatum in the rat. A study using anterograde transport of Phaseolus vulgaris-leucoagglutinin. Neuroscience 23:103-112.

Hayes RJ, Vorel SR, Liu X, Spector J, Lachman H, Gardner EL (1999) Electrical stimulation of the basolateral nucleus of the amygdala reinstates cocaine-seeking behavior. Soc Neurosci Abstr 25:559.

Hooks MS, Duffy P, Striplin C, Kalivas PW (1994) Behavioral and neurochemical sensitization following cocaine self-administration. Psychopharmacology 115:265-272.

Hyttel J, Larsen JJ, Christensen AY, Arnt J (1985) Receptor-binding profiles of neuroleptics. Psychopharmacology [Suppl] 2: 9-18

Jaffe JH (1990) Drug addiction and drug abuse. In: Goodman and Gilman's the pharmacological basis of therapeutics (Gilman AG, Rall TW, Nies AS, Taylor P, eds), pp 522-557. New York: Pergamon.

Kelley AE, Domesick VB, Nauta WJH (1982) The amygdalostriatal projection in the rat-an anatomical study by anterograde and retrograde tracing methods. Neuroscience 7:615-630.

Koob GF (1988) Cellular and molecular mechanisms of drug dependence. Science 242:715-723.

Maldonado R, Robledo P, Chover AJ, Caine SB, Koob GF (1993) D1 dopamine receptors in the nucleus accumbens modulate cocaine selfadministration in the rat. Pharmacol Biochem Behav 45:239-242.

McGregor A, Roberts DC (1993) Dopaminergic antagonism within the nucleus accumbens or the amygdala produces differential effects on intravenous cocaine self-administration under fixed and progressive ratio schedules of reinforcement. Brain Res 624:245-252.

Milliken GA, Johnson DE (1984) Analysis of messy data. Volume 1: Designed experiments. Belmont, CA: Lifetime Learning Publications.

O’Donnell P, Greene J, Pabello N, Lewis BL, Grace AA (1999) Modulation of cell firing in the nucleus accumbens. Ann NY Acad Sci 877:157-175.

Paxinos G, Watson C (1986) The rat brain in stereotaxic coordinates, Ed 2. San Diego: Academic.

Phillips AJ, Di Ciano P (1996) Behavioral sensitization is induced by intravenous self-administration of cocaine by rats. Psychopharmacology 124:279-281.

Phillipson OT, Griffiths AC (1985) The topographic order of inputs to the nucleus accumbens in the rat. Neuroscience 16:275-296.

Pierce RC, Kalivas PW (1997) A circuitry model of the expression of behavioral sensitization of amphetamine-like psychostimulants. Brain Res Rev 25:192-216.

Pierce RC, Bell K, Duffy P, Kalivas PW (1996) Repeated cocaine augments excitatory amino acid transmission in the nucleus accumbens only in rats having developed behavioral sensitization. J Neurosci 16:1550-1560.

Pierce RC, Reeder DC, Hicks J, Morgan ZR, Kalivas PW (1998) Ibotenic acid lesions of the dorsal prefrontal cortex disrupt the expression of behavioral sensitization to cocaine. Neuroscience 82:1103-1114.

Reid MS, Berger SP (1996) Evidence for sensitization of cocaine-induced nucleus accumbens glutamate release. NeuroReport 7:1325-1329.

Self DW, Nestler EJ (1998) Relapse to drug-seeking: neural and molecular mechanisms. Drug Alcohol Depend 51:49-60.

Self DW, Barnhart WJ, Lehman DA, Nestler EJ (1996) Opposite modulation of cocaine-seeking behavior by D1- and D2-like dopamine receptor agonists. Science 271:1586-1589.

Self DW, Genova LM, Hope BT, Barnhart WJ, Spencer JJ, Nestler EJ (1998) Involvement of cAMP-dependent protein kinase in the nucleus accumbens in cocaine self-administration and relapse of cocaineseeking behavior. J Neurosci 18:1848-1859.

Spealman RD, Barret-Larimore RL, Rowlett JK, Platt DM, Khroyan TV (1999) Pharmacological and environmental determinants of relapse to cocaine-seeking behavior. Pharmacol Biochem Behav 64:327-336.

Swanson LW (1982) The projections of the ventral tegmental area and adjacent regions: a combined fluorescent retrograde tracer and immunofluorescence study in the. Brain Res Bull 9:321-353.

Tran-Nguyen LTL, Fuchs RA, Coffey GP, Baker DA, O'Dell LE, Neiswander JL. (1998) Time-dependent changes in cocaine-seeking behavior and extracellular dopamine levels in the amygdala during cocaine withdrawal. Neuropsychopharmacology 19:48-59.

Weissenborn R, Deroche V, Koob GF, Weiss F (1996) Effects of dopamine agonists and antagonists on cocaine-induced operant responding for a cocaine-associated stimulus. Psychopharmacology 126:311-322.

White FJ, Kalivas PW (1998) Neuroadaptations involved in amphetamine and cocaine addiction. Drug Alcohol Depend 51:141-153.

Wise RA, Rompre PP (1989) Brain dopamine and reward. Annu Rev Psychol 40:191-215.

Wolf ME (1998) The role of excitatory amino acids in behavioral sensitization to psychomotor stimulants. Prog Neurobiol 54:679-720.

Worley CM, Valadez A, Shenk S (1994) Reinstatement of extinguished cocaine-taking behavior by cocaine and caffeine. Pharmacol Biochem Behav 48:217-221. 